\title{
CATELANUS AND FUSIMORPHUS (COLEOPTERA, ELATERIDAE, AGRYPNINAE)
}

Sônia A. Casari ${ }^{1,2}$

\begin{abstract}
The historical review and the diagnosis for the monotypical genera Catelanus Fleutiaux, 1942 and Fusimorphus Fleutiaux, 1942 are presented. Catelanus trilineatus (Castelnau, 1836) and Fusimorphus submetallicus (Fleutiaux, 1924) are redescribed and illustrated and new diagnostic characters are raised up. The historical review and the discussion on the remainder Neotropical genera of Hemirhipini are also included.
\end{abstract}

KEYWORDS. Agrypninae, Catelanus, Fusimorphus, Hemirhipini, Taxonomy.

\section{INTRODUCTION}

The tribe Hemirhipini is formed by 21 genera (CASARI-ChEN, 1994; CASARI, 1996b), distributed by all over the world. Nine genera and about 92 species are recorded from Neotropical region. A phylogenetic hypothesis for the genera of this tribe was proposed by CASARI-CHEN (1994), based on the study of the larger number of species available in each genus. This work evidenced that several genera included non congeneric species, and specific revisions were required. The historical review of the Neotropical genera is presented.

The genus Lacais Fleutiaux, 1942, was erected for Iphis glauca Castelnau, 1836. Fleutiaux (1942) included the note "Je suppose que les espèces suivantes, que me sont inconnues, devront sans doute entrer dans ce genre: Calais nietoi Sallé, 1873... Alaus plebejus Candèze, 1874... Alaus suturalis Champion, 1894... Et peut-être aussi Alaus griseus Candèze, 1881...”. CASARI-CHEN (1991) studying these species concluded that, besides the type species, only Lacais nietoi and L. suturalis belong to this genus; Alaus plebejus and A. griseus were kept in Alaus. At moment, this genus is formed by three species recorded from Mexico and Central and South America.

The study of a large series of all species included in Alaus Eschscholtz, 1829 let CASARI (1996a) concluded that three species were synonyms: $A$. canadensis Candèze, $1889=$ A. myops (Fabricius, 1810); A. primarius Candèze, $1865=$ A. patricius Candèze,

1. Museu de Zoologia, Universidade de São Paulo, Caixa Postal 42594, 04299-970 São Paulo, SP, Brasil. (casari@usp.br)

2. Bolsista CNPq. 
1857; A. griseus Candèze, $1881=A$. plebejus Candèze, 1874. Two species, $A$. calcaripilosus and $A$. veracruzanus, were described and the genus is, at moment, formed by 11 species, recorded from North, Central and South America.

The genus Chalcolepis Candèze, 1857 was monotypical until 1999 when CASARI described three species. The genus is formed by four species, recorded from Mexico and Central and north of South America.

Chalcolepidius Eschscholtz, 1829 is the larger Neotropical genus of Hemirhipini with 88 catalogued species. The study of large series of the majority of species revealed that three species were not congeneric and were removed from the genus, and 34 species were synonyms. Besides, two species were revalidated and 12 species were described. The genus is formed by 63 species, recorded from North, Central and South America.

Fleutiaux (1942) erected three genera, Pherhimius, Catelanus and Fusimorphus, to include the species not congeneric with Hemirhipus Latreille, 1825. CASARI (1996b) revised the genus Pherhimius, originally including six species and concluded that only two of them belong to this genus. A new genus, Saltamartinus Casari, 1996, was erected for the remainder species. The revision of Hemirhipus (CASARI, 1998) showed that, three species were synonyms: $H$. bonvouloirei Candèze, 1874=H. apicalis Candèze, $1857 ; H$. ferrugineus Candèze, 1893=H. bimaculatus Candèze, 1857; H. intermedius Golbach, 1976 $=H$. hougeti (Candèze, 1889). The genus is now formed by 9 species, recorded from Central and South America. The remainder two genera, Catelanus and Fusimorphus are herein studied.

The material studied belongs to DZUP (Departamento de Zoologia, Universidade Federal do Paraná, Curitiba, Paraná); MNRJ (Museu Nacional, Universidade Federal do Rio de Janeiro, Rio de Janeiro); and MZSP (Museu de Zoologia, Universidade de São Paulo, São Paulo).

\section{Catelanus Fleutiaux, 1942}

Catelanus Fleutiaux, 1942:112, 116; Casari-Chen, 1985:408; Golbach, 1976:27; 1994:26.

Type species: Hemirhipus trilineatus Castelnau, 1836, by monotypy.

Fleutiaux (1942) erected Catelanus for Hemirhipus trilineatus. He presented a generic key for, besides Hemirhipus, the genera established based on species segregated from the latter, including Catelanus. Golbach (1976) presented key for the genera and species of "subfamilia Hemirhipinae" from Central and South America, characterizing Catelanus by first time. In 1994, he presented a catalogue and keys to subfamily and genera of Elateridae from Central and South America. CASARI-CHEN (1985) presented the generic diagnosis, and in 1994 included Catelanus in the phylogeny of the Hemirhipini genera.

The genus Catelanus is characterized especially by integument very bright with glabrous appearance, yellow with longitudinal bands from ferrugineous to black, on pronotum and elytra, mesosternal cavity declivous on distal $2 / 3$, tergite VIII of male 1.4 times longer than wide, median lobe of aedeagus constricted near base and apex of ovipositor bearing a tuft of setae. 


\section{Catelanus trilineatus (Castelnau, 1836)}

(Figs. 1-19)

Hemirhipus trilineatus Castelnau, 1836:12, 13; Germar, 1840:272; Candèze, 1857:247, 251; 1874:154; 1891:36 (cat.); SChenkling, 1925:53; BLACKWELDer, 1944:282.

Hemirhipus quinquesignatus CASTELnaU, 1840:234. [Synonymized with $H$. trilineatus by CANDĖze, 1857:251].

Hemirhipus quinquelineatus CASTelnau, 1840:234, t. 16, f.1. [Synonymized with $H$. trilineatus by Fleutiaux, 1942:111].

Catelanus trilineatus; Fleutiaux, 1942:112, 116; Golbach, 1976:27; Casari-Chen, 1985:408.

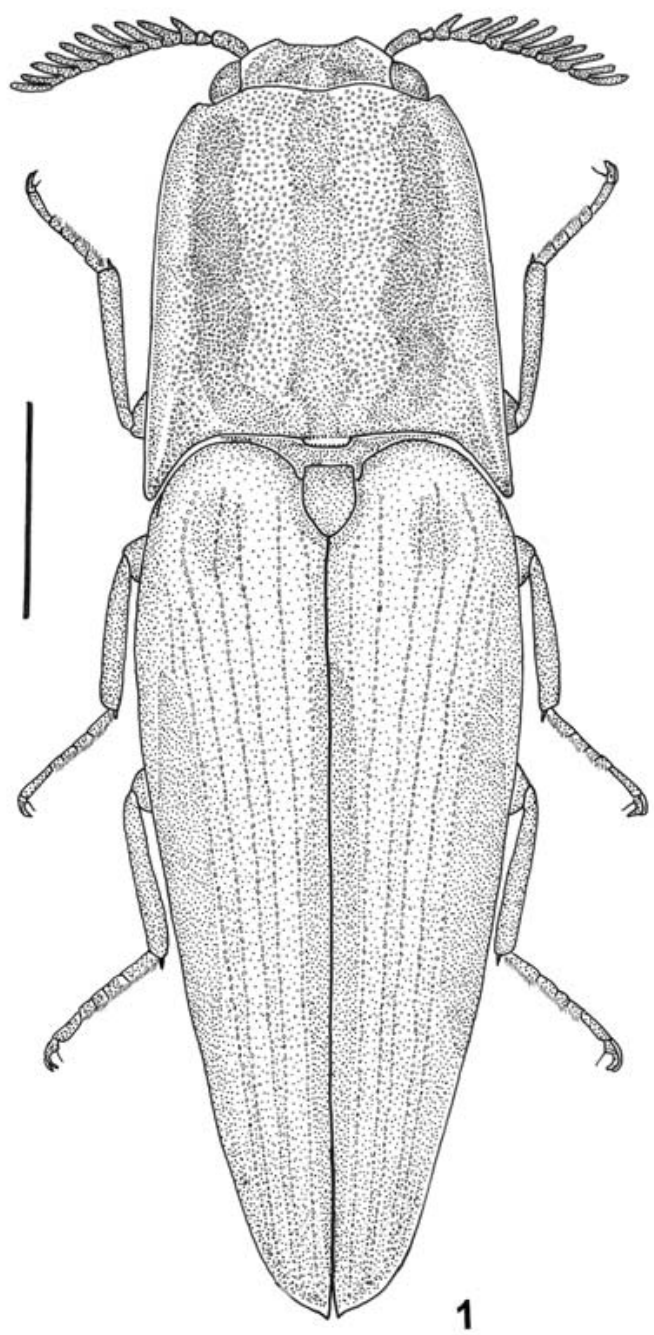

Fig.1. Catelanus trilineatus (Castelnau, 1836): dorsal habitus (female). Bar $=5 \mathrm{~mm}$. 
The original description of Hemirhipus trilineatus is based on material from Brazil. Any other data on the locality, besides "Brasilia", was included in the redescription of Germar (1840). CANDĖze (1857) divided the Hemirhipus species into two sections, based on scutellum shape; $H$. trilineatus belongs to group with "Écusson allongé, déclive". He considered $H$. quinquesignatus as a synonym of $H$. trilineatus. According to him, "M. Laporte de Castelnau, dans son Histoire Naturelle des Insectes, a décrit, sous le nom d'H. quinquesignatus, nom appliqué par Dejean à cet insecte, l'espèce dont il avait déjà publié la description dans la Revue de Silbermann, em 1834. Le nom de trilineatus, qu'il lui avait alors donné, doit être conservé comme le plus ancien". He also presented three variations for this species: "var. a. Prothoracis vittis lateralibus integris"; "var. b. Elytrorum, marginatibus suturalibusque vittis antrorsum nigrescentibus"; "var. c. Scutello rufo". All these variations were found into the material studied.

FLEUTIAUX (1942) considered, besides H. quinquesignatus, also H. quinquelineatus, synomym of $H$. trilineatus. Schenkling (1925) and Blackwelder (1944) followed Fleutiaux (l.c.). CAsari-Chen (1985) studied the mouthparts and the hindwings of $C$. trilineatus.

Redescription. Length: 22-38 mm. Integument bright, from yellow to ferrugineous; frons ferrugineous-yellow with triangular median basal, and sometimes, irregular median anterior, blackspot; pronotum ferrugineous-yellow with three longitudinal elliptical black bands, usually not reaching margins and lateral interrupted near base; in some specimens longitudinal median band of pronotum reaches anterior margin or, lateral bands broken or three bands are fused at base (figs. 3, 4); elytra yellow on basal fourth, gradually ferrugineous apicad; each elytron with narrow sutural band and lateral wide black band on distal 3/4; scutellum from yellow with brown borders to totally black (fig. 1). Prosternum with longitudinal median elliptical black band, absent in some specimens; ventrites yellow with longitudinal median darker band varying from narrow band to reaching almost whole ventrite width; patches brown with black borders. Pubescence simple, ferrugineous on frons and pronotum and yellowish on elytra; ventrally, pubescence yellowish-white and longer; tibiae bearing long and bristle setae; tarsal segments with ventral thick setae and claws with one long basal seta.

Frons wide, narrowed on distal fourth, slightly concave medioanteriorly and carinate on anterior margin; punctation small and dense and longitudinal median elliptical tubercle at base. Nasal plate high, parallel and punctate. Antennae 12-segmented and flabellate in both sexes; 3rd segment bearing long spiniform appendix (fig. 1). Pronotum (figs. 1, 3, 4) longer than wide, slightly narrowed apicad; lateral margins forming narrow edge; strongly convex from edge; densely small-punctate; anterior margin sinuous; hind angles backwards, slightly divergent, strongly raised at middle (not forming carina); median basal tubercle rounded. Prosternum (fig. 2) strongly convex from sutures; punctation coarse and sparse, more concentrate near sutures; prosternal lobe rounded with sparse punctation. Notosternal sutures (fig. 2) almost straight. Punctation of hypomera (fig. 2) weak, small and sparse. Mesosternal cavity (fig. 2) U-shaped with borders wide and horizontal on basal third and narrow and declivous on distal 2/3. Metasternum smallpunctate, with carina parallel mesocoxal cavity. Metacoxal plate (fig. 2) slightly narrowed laterally. Last visible sternite narrowed apicad, with rounded apex in both sexes. Tibial spurs present. Scutellum elongate (figs. 5-8) and declivous; shapes variable. Elytra (fig. 1) 


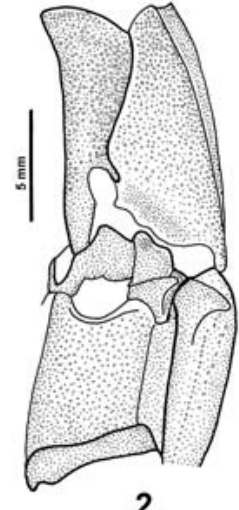

2

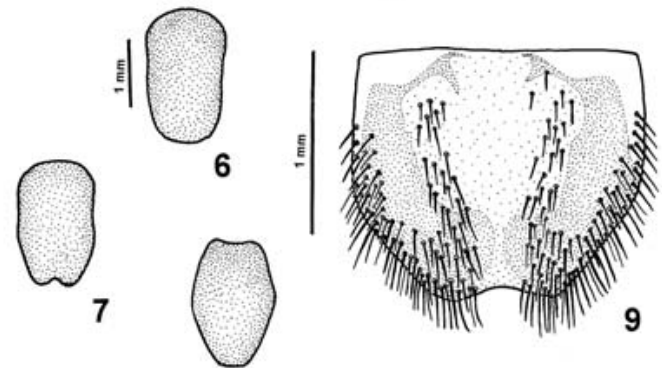

8

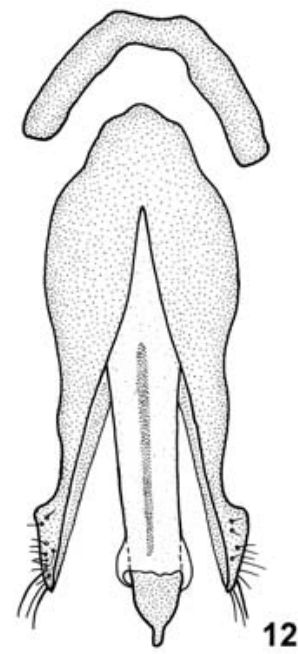

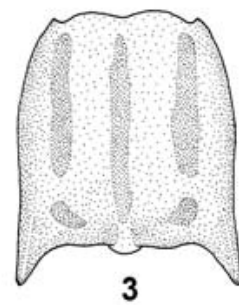

5
9

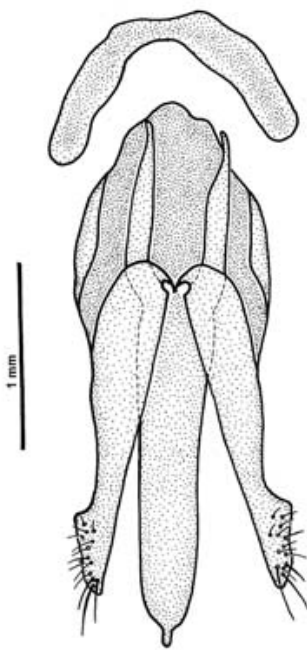

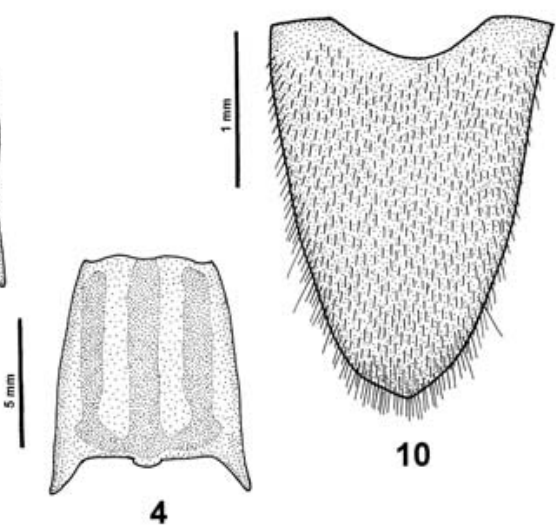

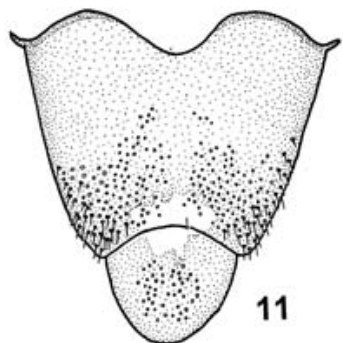

13

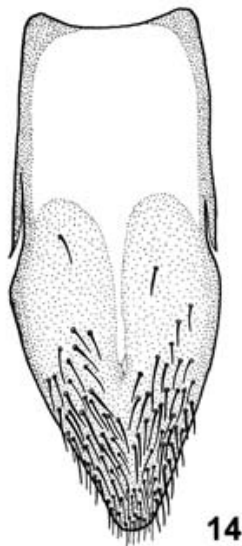

Figs. 2-14. Catelanus trilineatus (Castelnau, 1836), male: 2, thorax (ventrolateral); 3, 4, pronotum; 58, scutellum; 9, sternite VIII; 10, tergite VIII; 11, tergites IX-X; 12, 13, aedeagus (ventral, dorsal); 14, sternite IX. Figs. 3,$4 ; 5-8 ; 9,11 ; 10,14 ; 12,13$, to same scale. 

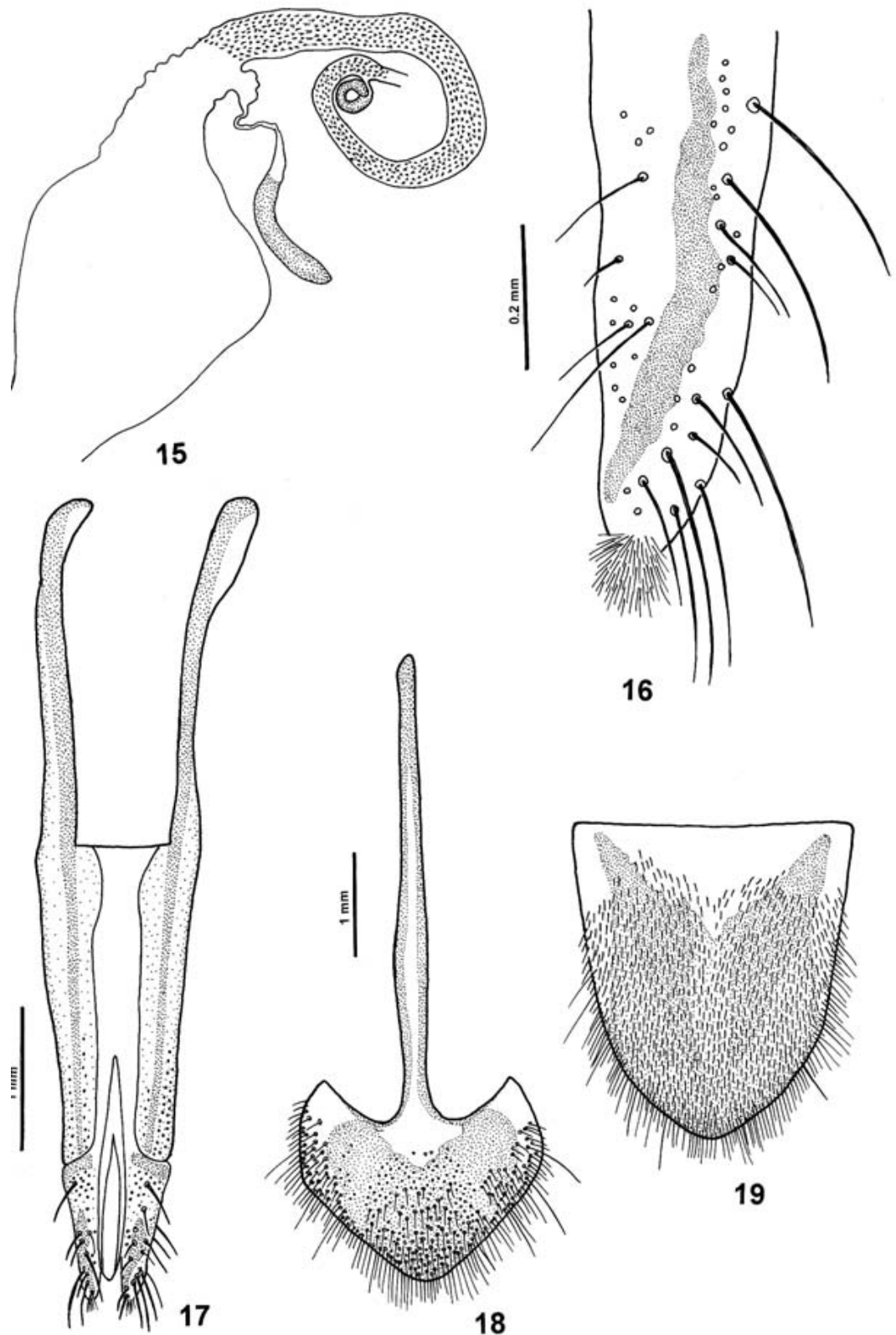

16

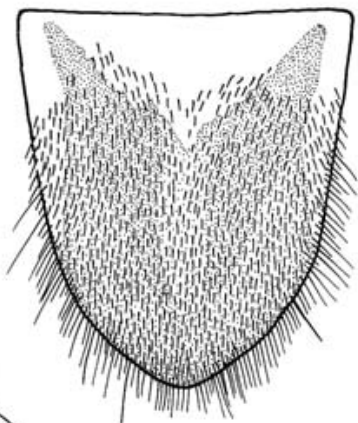

19

Figs. 15-19. Catelanus trilineatus (Castelnau, 1836), female: 15, bursa copulatrix; 16, apex of ovipositor (ventral); 17, ovipositor (ventral); 18, sternite VIII; 19, tergite VIII. Figs. 15, 17; 18, 19, to same scale. 
punctate-striate; striae marked by row of coarse punctures; interstices flat and very small-punctate, unequal in width; apices with small sutural spine.

Genital segments of male and aedeagus. Tergite VIII (fig. 10) elongate, narrowed apicad; densely clothed with short setae. Sternite VIII (fig. 9) transverse, narrowed on distal half; distal margin slightly notched at middle; moderately long setae near lateroanterior margins and on two longitudinal bands near middle. Sternite IX (fig. 14) elongate, narrowed apicad on distal half; distal third setous. Tergite IX (fig. 11) transverse, punctate, narrowed apicad; distal margin moderately notched at middle; short setae lateroanteriorly; tergite X semi-elliptical and punctate at middle. Aedeagus (figs. 12, 13): parameres securiform distally; median lobe constricted near base and at apex.

Genital segments and genitalia of female. Tergite VIII (fig. 19) elongate, narrowed apicad; distal margin prominent at middle; densely clothed with setae, longer at margins. Sternite VIII (fig. 18) transverse, narrowed apicad; distal margin strongly prominent at middle; clothed with moderately long setae, longer at margins; spicullum gastrale 2.8 times longer than sternite. Genitalia: ovipositor (figs. 16, 17) with several dorsal and ventral long setae and a tuft of shorter and clearer at apex; bursa copulatrix (fig. 15) narrow, long and spiny internally; two spermatheca: basal elongate and distal spiral-like.

Material examined. BRAZIL, Pará: Belém, :- (MZSP); Minas Gerais: : (MZSP); Rio de Janeiro: Rio de Janeiro (Corcovado), '- (MNRJ); Serra dos Órgãos, 3 '- (MNRJ); São Paulo: Itararé, '- (MZSP); São Paulo (Cantareira), '’, 2 '- (MZSP); Paraná: Rolândia, '’'(MZSP); Santa Catarina: Mafra, '- (MZSP); Pinhal, 5 ' (MNRJ), '(dissected), $2 \div$ (MZSP).

\section{Fusimorphus Fleutiaux, 1942}

Fusimorphus Fleutiaux, 1942:111, 116; Golbach, 1976:17; 1994:26; Casari-Chen, 1985:412.

Type species: Hemirhipus submetallicus Fleutiaux, 1924, by monotypy.

Fusimorphus was firstly defined in the Fleutiaux (1942) key, together with the other genera erected from Hemirhipus species. The first description of the genus was presented by Golbach (1976). In 1994, this author presented a catalogue and keys to subfamily and genera of Elateridae from Central and South America. CASARI-CHEN (1985) presented a generic diagnosis and in 1994 included Fusimorphus in the phylogeny of the Hemirhipini genera.

The genus Fusimorphus is characterized especially by fusiform body, integument of elytra with metallic reflex, scutellum folded at middle, hind angles of pronotum constricted at apex and apex of ovipositor with membranous setous lobe.

\section{Fusimorphus submetallicus (Fleutiaux, 1924)}

(Figs. 20-32)

Hemirhipus submetallicus Fleutiaux, 1924:184; Blackwelder, 1944:282.

Fusimorphus submetallicus; Fleutiaux, 1942:116; CASARI-Chen, 1985:412.

Fleutiaux (1924) described Hemirhipus submetallicus based on three specimens from French Guiana (Nouveaux Chantier). He stated: "Très jolie espèce qui ne peut être comparée à aucune de celles connues". I believe that he referred to violet-blue reflex of the elytra. 


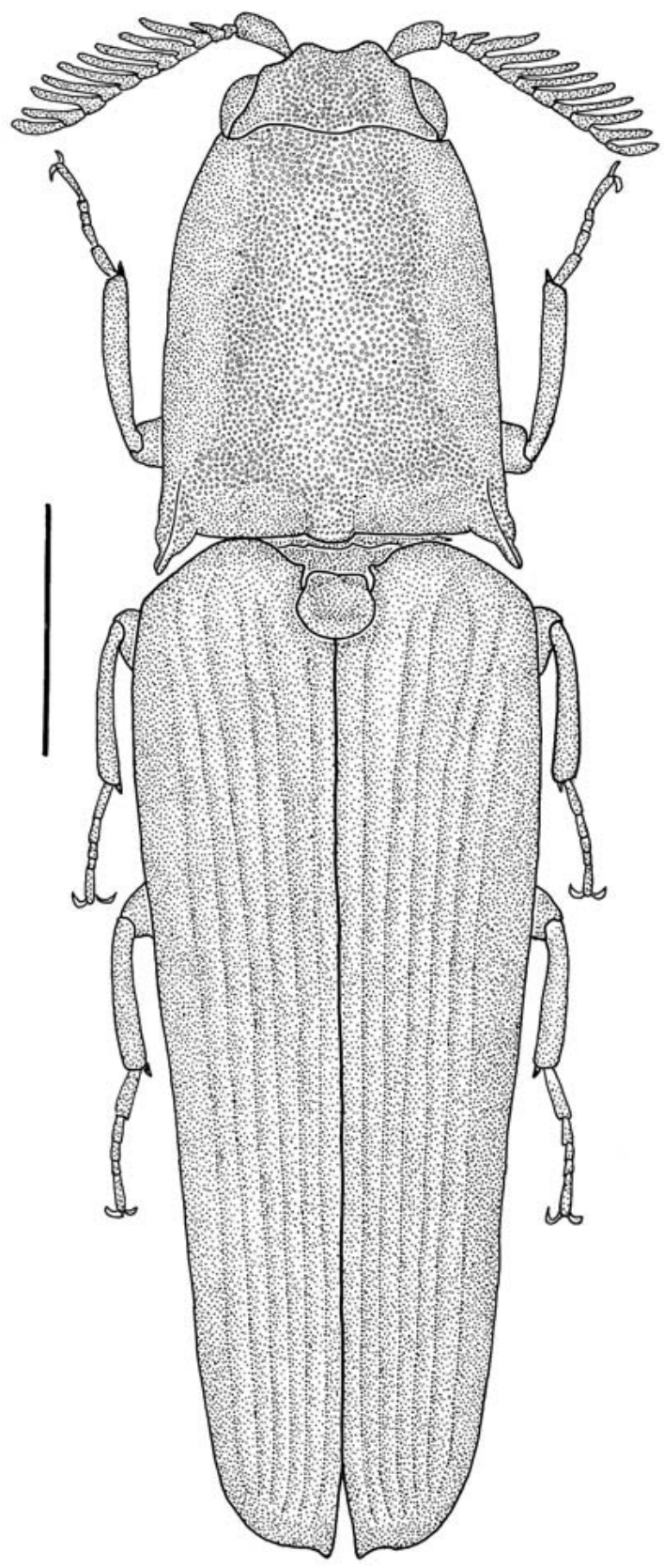

Fig. 20. Fusimorphus submetallicus (Fleutiaux, 1924), dorsal habitus (female). Bar $=5 \mathrm{~mm}$. 

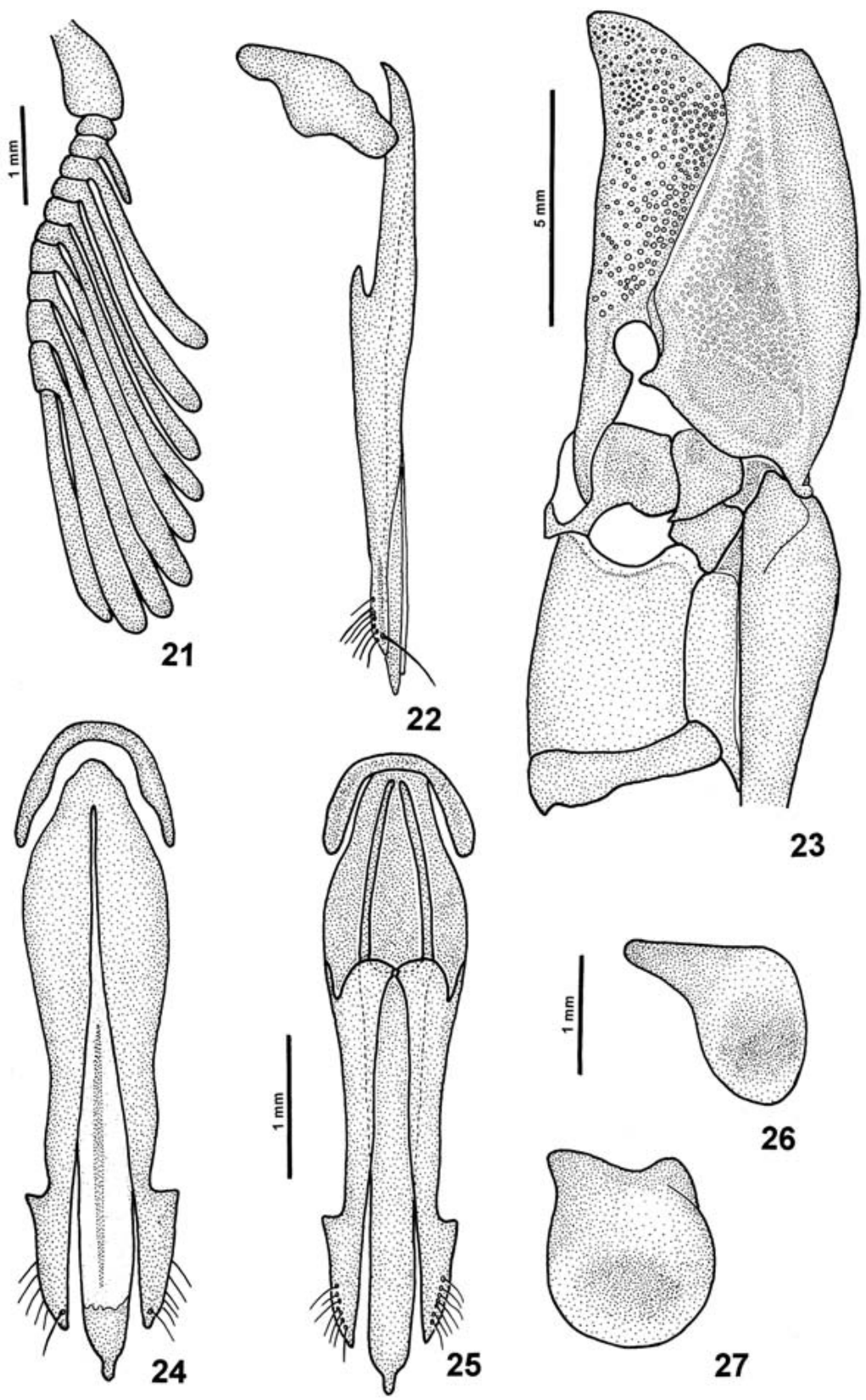

27

Figs. 21-27. Fusimorphus submetallicus (Fleutiaux, 1924), male: 21, antenna; 22, 24, 25, aedeagus (lateral, ventral, dorsal); 26, 27, scutellum (lateral, dorsolateral). Figs. 22, 24, 25; 26, 27, to same scale. 


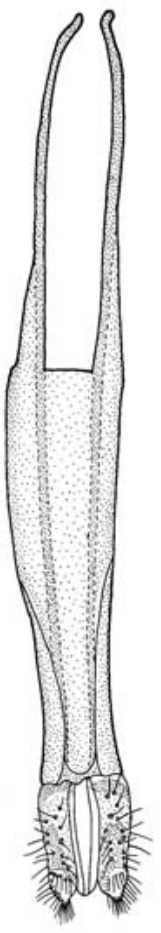

28

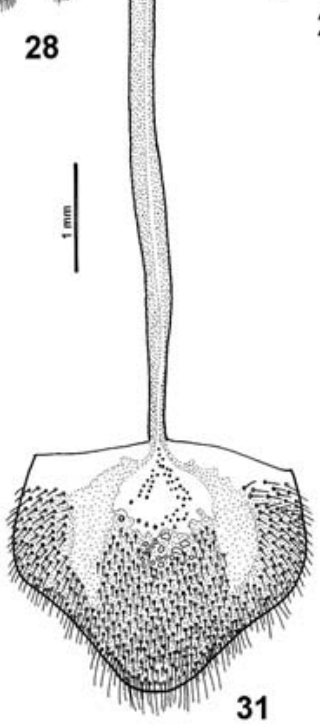

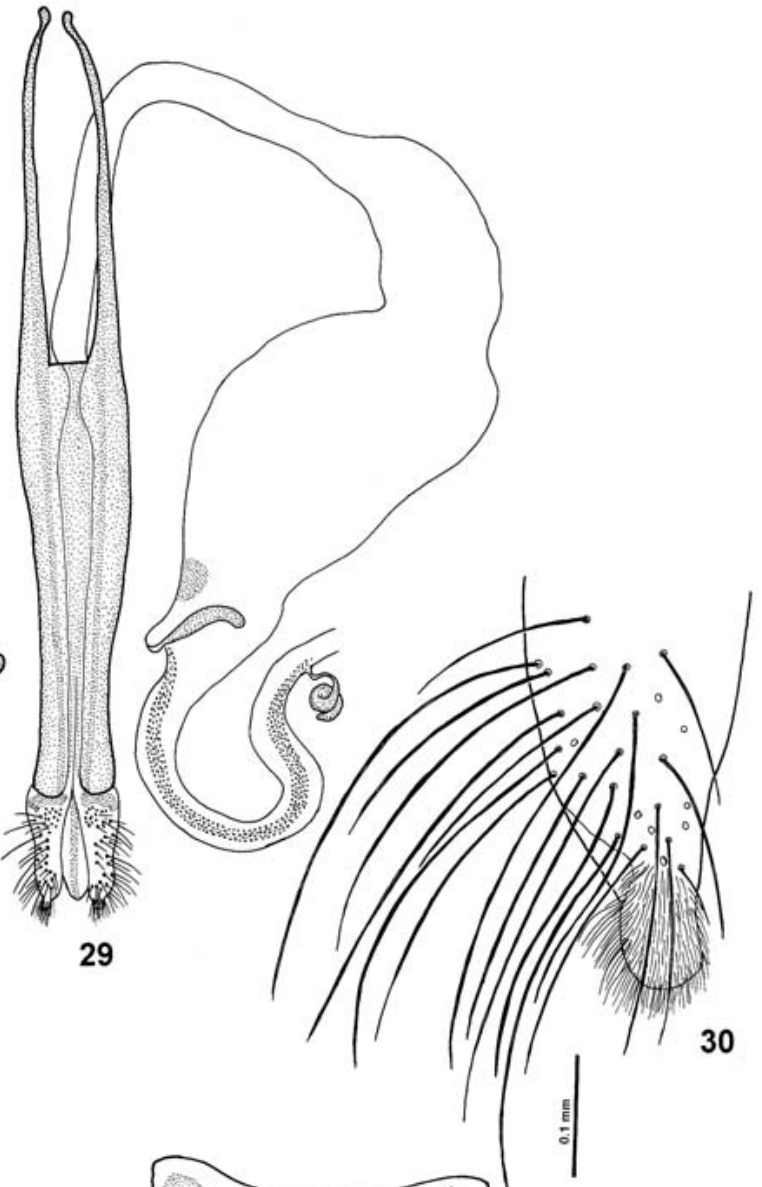

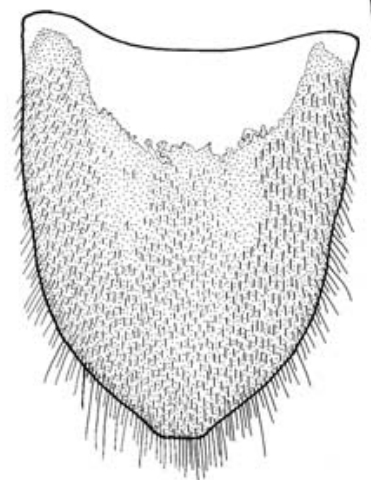

32

Figs. 28-32. Fusimorphus submetallicus (Fleutiaux, 1924), female: 28, ovipositor (ventral); 29, genitalia (dorsal); 30, apex of ovipositor; 31, sternite VIII; 32, tergite VIII. Figs. 28, 29; 31, 32, to same scale. 
Redescription. Length: 30-31 mm (fig. 20). Integument bright, from dark-brown to black, with legs and antennae clear-brown; one specimen with elytra metallic blue. Pubescence thin, whitish, longer ventrally on meso- and metathorax.

Frons narrow on distal third with anterior margin carinate; concave medioanteriorly with fore angles raised; punctation moderately coarse and dense. Nasal plate high, concave and punctate. Antennae flabellate and 12-segmented in both sexes, longer in male (fig. 21).

Pronotum (fig. 20) longer than wide, slightly narrow apicad; strongly convex from lateral margins; punctation moderately coarse and dense with lateral margins forming smooth band; anterior margin sinuous; hind angles divergent, with apex smooth and constricted; median basal tubercle smooth, bright and rounded. Prosternum (fig. 23) strongly convex from sutures, with very coarse and sparse punctation, more concentrate near sutures and lateroanteriorly. Prosternal lobe strongly rounded with coarse punctation, more concentrate near anterior margin. Prosternal sutures straight (fig. 23). Hypomera concave, densely punctate except lateral margins, irregular band near each suture and basal band; punctation umbilicate; raised narrow smooth band near sutures. Mesosternal cavity wide and rounded with borders narrow and excavate at middle. Mesosternum densely small punctate. Metacoxal plate (fig. 23) slightly narrowed laterally. Tibiae bearing rows of spiniform setae, longitudinally on anterior and posterior faces and marginally at apex; tibial spurs present; tarsal segments bearing spiniform setae ventrally; each claw with one long basal seta. Last visible sternite with apex slightly rounded in both sexes. Scutellum (figs. 26, 27) folded at middle, taking an angular shape, not making transverse carina at middle; horizontal half concave at posterior half and raised anteriorly. Elytra striate and densely small-punctate; interstices convex, equal in width; apices bearing sutural spine.

Aedeagus (figs. 22, 24, 25): narrow; median lobe 1.4 times parameres length, slightly narrow apicad, with constricted apex; apex of parameres securiform with lateral setae.

Genital segments and genitalia of female. Tergite VIII (fig. 32) elongate with distal margin rounded and prominent at middle; translucent at base; densely setous; marginal setae longer. Sternite VIII (fig. 31) subtriangular, anterior margin strongly prominent at middle; densely setous; spiculum gastrale very long, almost three times longer than sternite. Genitalia: ovipositor (figs. 28-30) without styli, bearing setous lobe at apex; bursa copulatrix (fig. 29) narrow and spiny internally; two spermathecae, basal elongate and distal spiral-like.

Material examined. BRAZIL, Amazonas: Rio Juruá, '- (MZSP); Rondônia: '- (DZUP). This locality reported in the literature as French Guiana, Nouveau Chantier.

Remarks. According to CASARI-Chen (1994) Catelanus and Fusimorphus belong to subtribe Hemirhipina, especially by the antennae flabellate and 12-segmented in both sexes. These two genera were included in different groups, separated especially by different coloration pattern and body shapes. Besides the characters above, the mesosternal cavity and the scutellum shapes and the lateral margins of pronotum are very different. The male and the female genitalia are very similar, especially the shape of parameres apex, bursa copulatrix and spermathecae. Both genera present same geographical distribution, wider in Catelanus. 


\section{REFERENCES}

Blackwelder, R. E. 1944. Checklist of Coleopterous insects of Mexico, Central America, the West Indies and South America. Bull. U. S. natn. Mus.,Washington, 185(2):280-303.

Candèze, E. 1857. Monographie des Élatérides. Tome premier. Mém. Soc. r. Sci. Liège, Liège, 12: $1-400,7$ est.

_. 1874. Révision de la Monographie des Élatérides. Mém. Soc. r. Sci. Liège, Liège, 4(ser. 2):1-218.

- 1891. Catalogue méthodique des élatérides connus en 1890. Liège, H. Vaillant-Carmanne. $246 \mathrm{p}$.

Casari-Chen, S. A. 1985. Sistemática e evolução dos Hemirhipini neotropicais (Pyrophorinae, Elateridae, Coleoptera). Revta bras. Ent., São Paulo, 29(3/4):383-423.

. 1991. Systematics and phylogenetic analysis of Lacais Fleutiaux, 1942 (Coleoptera, Elateridae, Pyrophorinae, Hemirhipini). Revta bras. Ent., São Paulo, 35(4):773-794.

1994. Systematics and evolution of Hemirhipini from Old World and Australia. II. Phylogeny of the tribe including the American genera (Coleoptera, Elateridae, Pyrophorinae). Revta bras. Ent., São Paulo, 38(1):161-252.

CAsari, S. A. 1996a. Systematics and phylogenetic analysis of Alaus Eschscholtz, 1829 (Coleoptera, Elateridae). Revta bras. Ent., São Paulo, 40(2):249-298.

1996b. Revision of Pherhimius Fleutiaux, 1942 with establishment of the Saltamartinus, new genus (Coleoptera, Elateridae, Pyrophorinae, Hemirhipini). Papéis Avuls. Zool., São Paulo, 39(21):379-403.

. 1998. Revision of Hemirhipus Latreille, 1825 (Coleoptera, Elateridae). Revta bras. Ent., São Paulo, 41(2-4):317-334.

1999. Three new species of Chalcolepis Candèze, 1857 (Col. Elateridae: Agrypninae: Hemirhipini). Annls Soc. ent. Fr., Paris, (N. S.), 35(2):203-215.

Castelnau, Comte de (Laporte, F. L. N.). 1836. Études entomologiques, ou descriptions d'insectes nouveaux et observations sur la synonymie. Rev. Entomol., Caen, 4:5-60.

1840. Histoire naturelle des animaux articulés. Paris. v. $1,324 \mathrm{p}$.

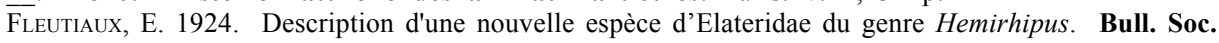
ent. Fr., Paris, 1924:183,184.

1942. Sur certains Hémirhipides (Col. Elateridae). Annls Soc. ent. Fr., Paris, 111:91-116.

Germar, E. F. 1840. Bemerkungen über Elateriden. Z. Ent., Leipzig, 2(2):241-278.

Golbach, R. 1976. Clave tentativa de los generos y especies de la sub-familia Hemirhipinae (Col. Elateridae) de Centro y Sudamerica. Acta zool. lilloana, Tucumán, 32(2):15-30.

1994. Elateridae (Col.) de la Argentina. Historia, catálogo actualizado hasta 1991 inclusive y clave de subfamilias y de géneros de Centro y Sudamérica. Op. lilloana, Tucumán, 41:1-48.

Schenkling, S. 1925. Elateridae I. Pars 80. In: Coleopterorum Catalogus auspiciis et auxilio W. Junk. Berlin, W. Junk. 263p.

Recebido em 05.02.2002; aceito em 03.07.2002. 